\title{
The Handprint, the Shower of Gold, and Thingness of Architecture
}

KRUNOSLAV IVANIŠIN

Faculty of Architecture, University of Zagreb 
Architecture is an eminently artificial human enterprise but subject to natural laws and principles residing somewhere between the mineral world and vegetation. It is eminently archaic, as the dominant epistemologies, pragmatic conditions and techniques may change, but fundamental notions, ideas and principles remain where they have been ever since the construction of the first shelter. Architecture is also eminently thingly. As a thing, every work of architecture is in opposition to our broken world of events. For better or for worse, in actual practice this opposition settles in the act of construction, as a project becomes a building: material, structure, space.

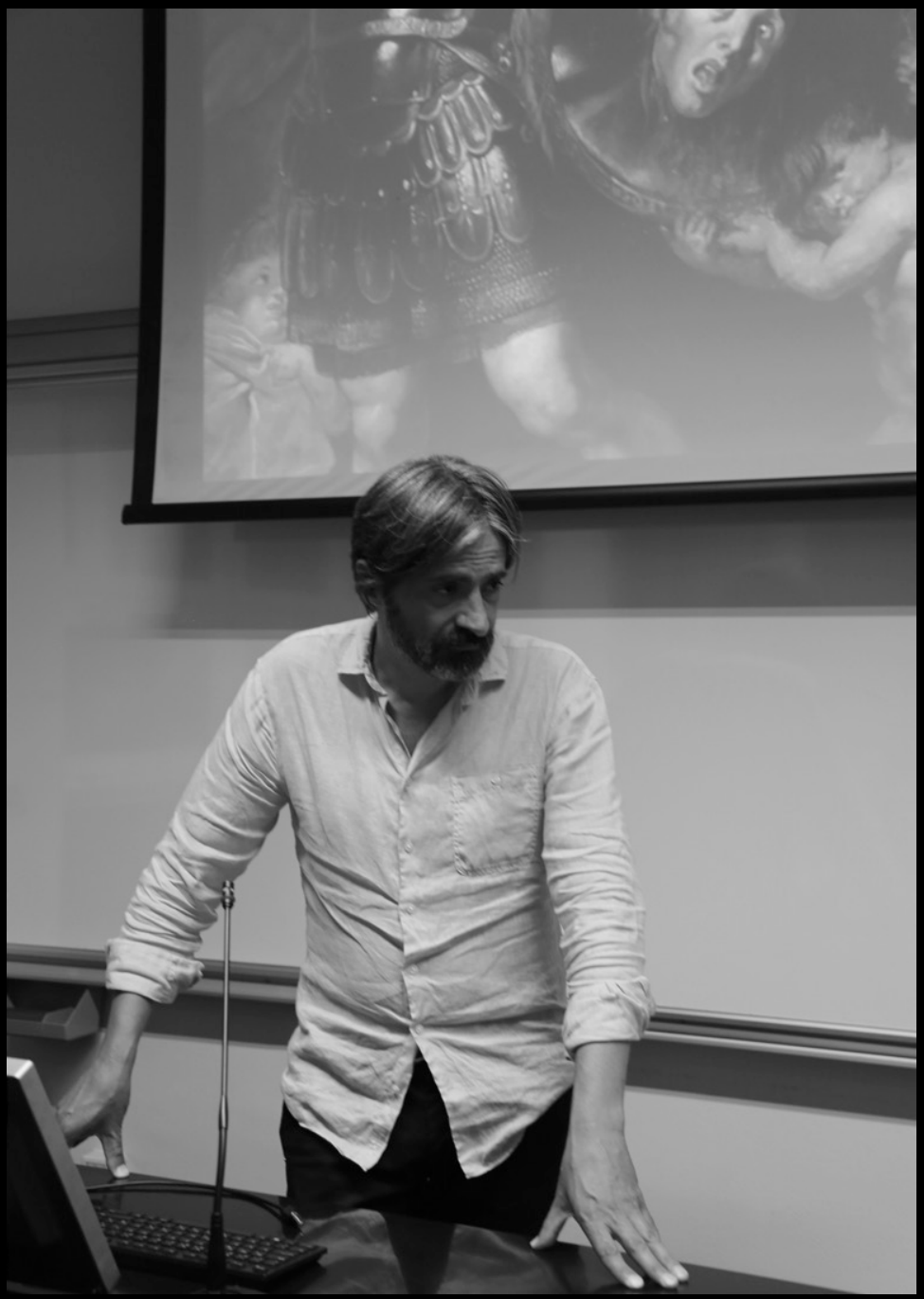


To grasp a beautiful thing or some difficult idea - the language clearly pronounces the hand-to-mind connection. In the world of things, this connection manifests itself in a HANDPRINT that a humble craftsman leaves on a handy mud brick, the most ancient, most ordinary and most simple building material made of the same element we are made of - the earthy powder. The standard hand-pressed and sun-dried mud brick Hassan Fathy and his Nubian masons rescaled for the New Gourna project consists of ordinary earth from the site, sand from the desert, straw and water, the exact proportions depending on the required specific weight of the brick determined as a part of a wall, a vault or a dome. It is made smaller than the usual bricks to facilitate the handling and profiled with two parallel grooves drawn diagonally with the fingers from corner to corner of the largest surface. The craftsman's handprint enables the brick to stick to a muddy surface by suction once built into the right place (Fathy, 1989). For Richard Sennett's Craftsman, to grasp something implies physically to reach for it, and mentally to understand rather than simply perform the operation (Sennet, 2008). In Fathy's and his craftsmen's actual experience it meant more. In New Gourna, the craftsmanship was tailored not to the simple material needs of the people but to the material and spiritual needs of the "trinity" owner, architect and craftsman (Fathy, 1989). It was elevated to a heroic level, biblical certainly not in terms of physical proportion, and not only because of the biblical building material involved. Ten thousand years old tradition of building with dust, mud, plaster, adobe, from the ground of Jericho to the suspended Mocárabe domes of Alhambra was brought alive, a mythical experience as it were. In transition from essence towards presence, the craftsman's handprint on the New Gourna brick uncovers the thingness of things: their purpose, shape and matter. "Things" are in plural here because the thingness of each brick involves its final cause - the thingness of the pediment, the wall, the vault, the dome, and the whole building.

The mythical "Host of Many", the lord of shadows and everything inside earth including roots and springs, minerals and gems, lurks from the interior of a cave and comes into the light only briefly, to abduct the beautiful Proserpina (Evelyn-White, 2005). His strong grasp leaves the shadow on her white flesh, made known by the hand of Gian Lorenzo Bernini. Like that spirited craftsmen from New Gourna, the great artist uncovers the properties of the material - the stoniness and the whiteness of the white stone. Leaving his handprint, he virtually 


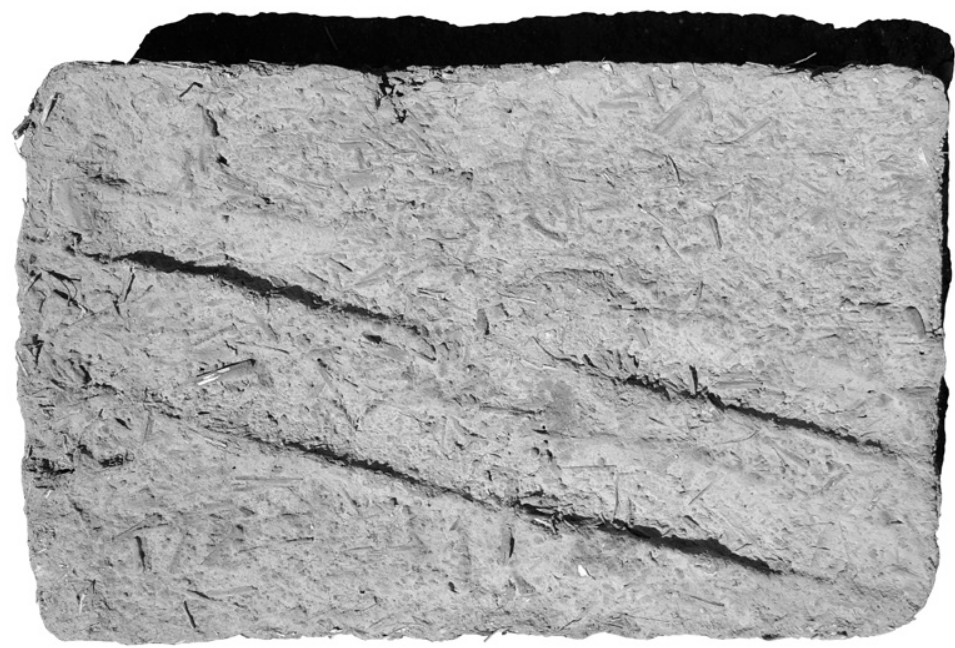

Fig. 1: Mud brick from New Gourna, Egypt, collection KI

brings things to life, chiseling shadow and light from the perfect block of Carrara marble. Taking a second look into whiteness through Sir Isaac Newton's prism, Johann Wolfgang von Goethe found color exactly in this area of transition between shadow and light, the mythical cave and glade - sunset and night, twilight at dawn and morning shine. With the sunset first comes the yellow as the light dampened by darkness, with the sunrise first comes the blue as the darkness weakened by light. Goethe was not interested in laboratory splitting of light in controlled dark-room conditions. Instead, he emphasized the phenomena and the perception of the actual phenomena found in nature. In this sense, a direct observation of how the sequences of colors appear and disappear against darkness and lightness above the silent sea surface may be edifying. As a giant mirror, the sea surface magnifies the sunrise and sunset spectacles.

"Should your glance on mornings lovely

Lift to drink the heaven's blue

Or when the sun, veiled by sirocco,

Royal red sinks out of view -

Give to Nature praise and honor.

Blithe of heart and sound of eye

Knowing for the world of colour

Where its broad foundations lie" 


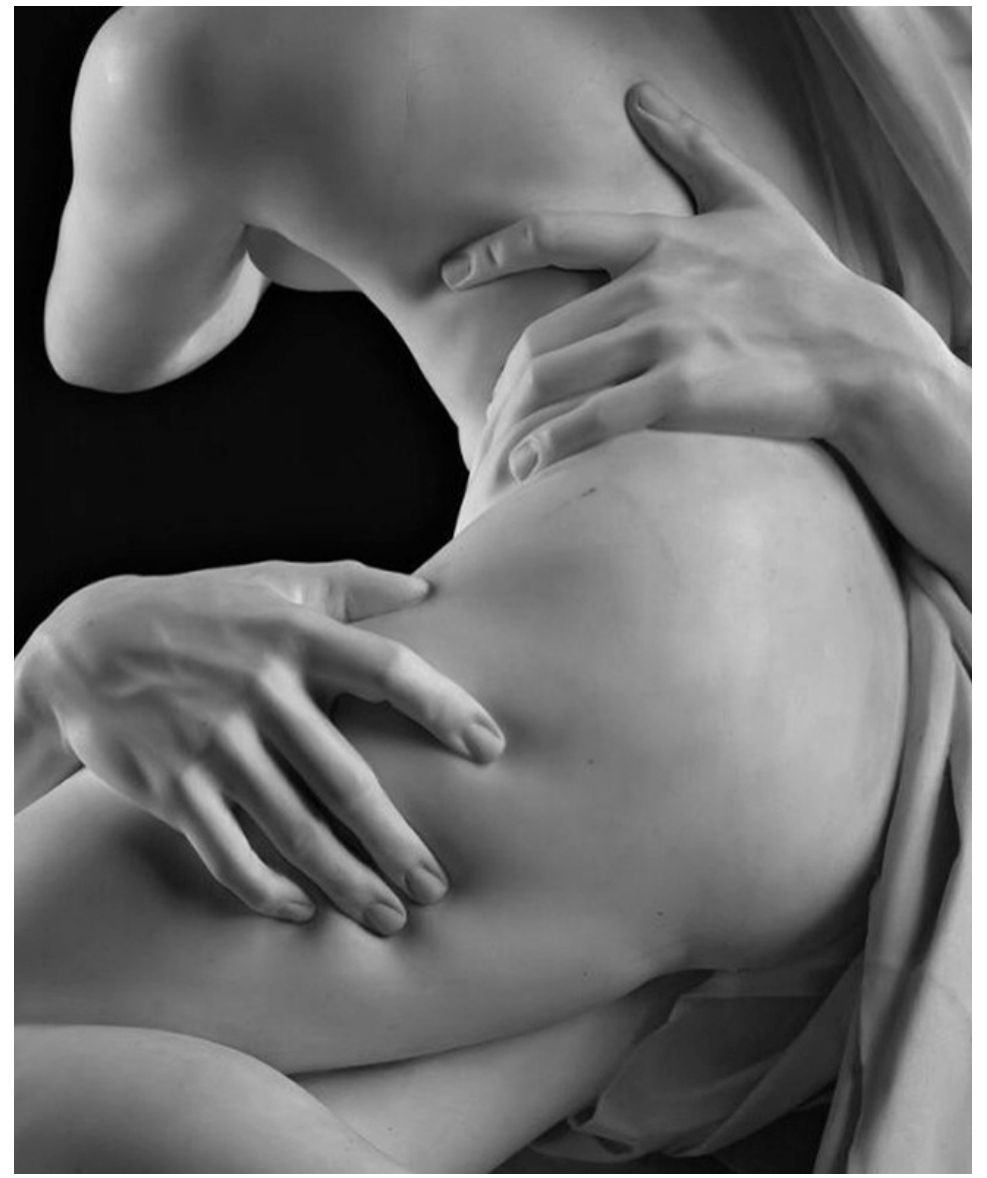

Fig. 2: Gian Lorenzo Bernini, Abduction of Proserpina, 1622, detail

Ridiculing the mechanicist Spiegel hüben - Spiegel drüben point of view, Goethe grasped that color is produced from the light, as much as by the thing itself on which the light falls - a property of its material and a consequence of its shape. In architecture, it is the zenithal light which virtually brings things to life. Within the Mocárabe dome in Alhambra the color appears from the adobe plaster, the spectacle of space from the thing itself. This chiseled receptacle of light from above is a celebration of the world of things. Suspended from heaven as it were, it is the best physical proof of the impossibility of emptiness as understood by Aristotle: the superlunary world is filled with aether, the quintessence, while in the sublunary world of the four natural elements the air, the liquid or the solid matter would infuse the void if it miraculously existed for some infinitely short moment. The medieval idea about the very first appearance of the blue from the darkness before the division of 


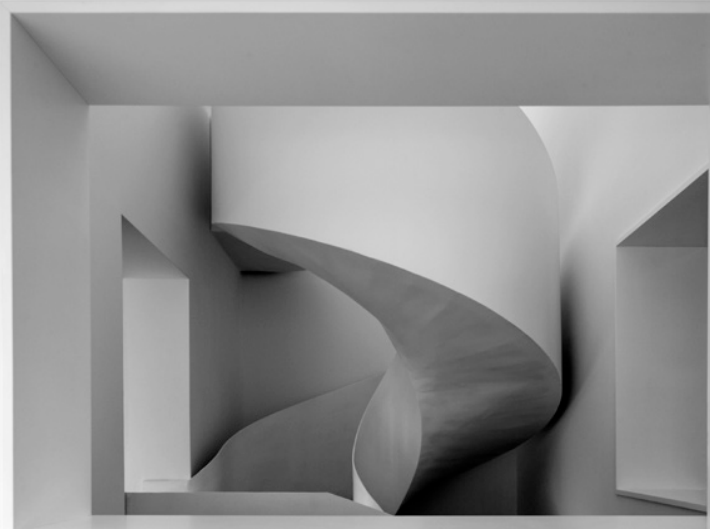

Fig. 3: IVANIŠIN. KABASHI. ARHITEKTI, Conception of Perseus - Abduction of Persephone, 2018 (photo: Miljenko Bernfest, 2019)

waters, "Let there be Light," is beautifully illustrated with the folio from the Nuremberg Chronicle (1493). It shows a double circle inscribed within a square with the inner circle filled with light blue pigment dissolving into the white towards the upper third of the circle. Probably the most verbatim celebration of zenithal light in architecture is the Quranic inscription in the dome of Hagia Sophia by master calligrapher Kazasker Mustafa around 1850. In place of the Pantocrator a "highly appropriate replacement" according to Titus Burckhardt, the Verse of Light (Burckhardt, 2009) is placed atop the golden dome, above the row of forty windows around the base, a bucket of golden light as it were, from outside and from the thin layer of gold itself. Metaphorically and literally - "God is the light of the heavens and the earth. The symbol of His light is a niche wherein is a lamp. The lamp is in a glass, and this glass is a radiant star. (The light) is nourished by a blessed olive tree, which is neither of the east nor of the west, whose oil would all but glow though fire touch it not. Light upon light. God guideth to His light whom he will, and God striketh symbols for man, and God knoweth all things" (Burckhardt, 2009). The mythical lord of sky and thunder from whom nothing can be hidden becomes the SHOWER OF GOLD - in Ovid's words - and enters from above into the beautiful princess' hidden chamber, to turn her dark prison into a pleasant place. According to Pausanias, Danae's uncle Proetus employed the antediluvian monsters to erect the cyclopean walls of Tiryns (Pausanias, translated by W.H.S. Jones, 1918), the most primitive monumental structure. Most probably, her father Acrisius employed the same primitive technique and same primitive builders in construction of the underground chamber without any definite outside appearance made to 

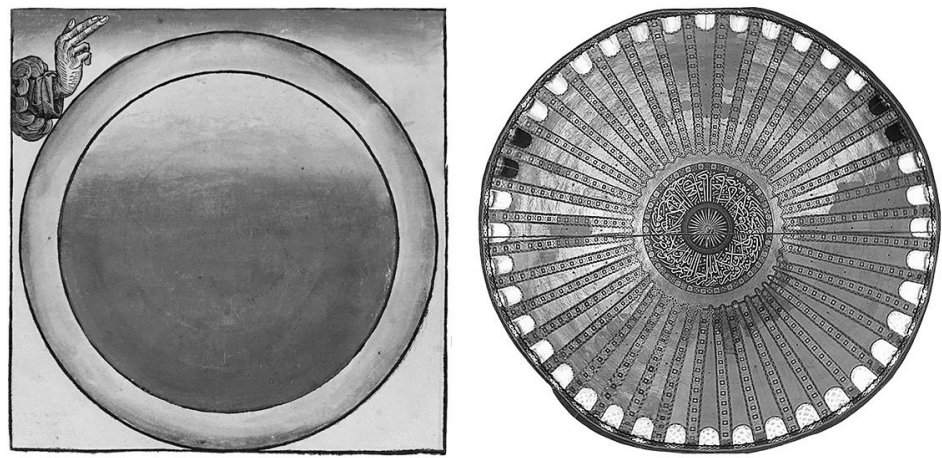

Fig. 4: "Let there be Light," from Nuremberg Chronicle, 1493, and Verse of Light in Hagia Sophia dome, 1850

protect Danae from the suitors. Only when the air enclosed within the cyclopean walls was infused with light from above and thus given some qualities of liquid and solid matter, did Danae's chamber become the original, primordial architecture. The mythical lord of sky and thunder from whom nothing can be hidden becomes the SHOWER OF GOLD - in Ovid's words - and enters from above into the beautiful princess' hidden chamber, to turn her dark prison into a pleasant place. According to Pausanias, Danae's uncle Proetus employed the antediluvian monsters to erect the cyclopean walls of Tiryns (Pausanias, translated by W.H.S. Jones, 1918).

The mythical lord of sky and thunder from whom nothing can be hidden becomes the SHOWER OF GOLD - in Ovid's words - and enters from above into the beautiful princess' hidden chamber, to turn her dark prison into a pleasant place. According to Pausanias, Danae's uncle Proetus employed the antediluvian monsters to erect the cyclopean walls of Tiryns (Pausanias, translated by W.H.S. Jones, 1918), the most primitive monumental structure. Most probably, her father Acrisius employed the same primitive technique and same primitive builders in construction of the underground chamber without any definite outside appearance made to protect Danae from the suitors. Only when the air enclosed within the cyclopean walls was infused with light from above and thus given some qualities of liquid and solid matter, did Danae's chamber become the original, primordial architecture. Elias Torres proposed a mental exercise of imagining oneself closed in a dark bottle, a canister or some other container with a tap, and the sensation of zenithal light in the interior of the container when the tap opens (Torres, 2009). The myth about how Perseus, the ideal hero who fights the darkness, was "conceived with joy beneath a shower of gold" (Ovid, 1958.) explains the discovery of space 
down in the world of things as a divine arrangement. In Mysterium Cosmographicum (1596), Johannes Kepler explained the spatial analogy between the world of four natural elements and the celestial spheres, in other words the sublunary world of things and the outer space. The discovery exemplified with the model of the Solar system as the concentric nest of five Platonic solids / Euclidean geometric bodies divided by inscribed and circumscribed spheres, whose spacings relatively match the distances of the six known planets from the sun came to him in the middle of a lecture. It displays his truly remarkable, in a way architectural spatial sense. In Astronomia Nova (1609), Kepler explained how, beside this spatial sense, it was the divine arrangement which enabled him a look into depths of space in the right moment and in the right direction, to clearly see the motion of celestial bodies. He arrived at Tycho Brahe's observatory in the moment they were observing the acronychal position of Mars, and it was only the observation of Mars which could have led Kepler to the discovery of the harmonious order of the Universe (Donahue, 2004). While observing the orbit of Mars from the moving platform displaced from the geometric center of the Universe, he was seeking to determine the nature of the broad Universe. While investigating the nature of the Universe, Kepler was also investigating the way he was able to investigate - the interaction of the visible parts of the Universe with our senses, the interaction of our senses with our mind, and the interaction of our mind with the Universe as a whole. The coherence between the laws of cognition and the laws of physics, i.e. the fact that the laws of physics are within the grasp of our mind, is reflected in his discovery of the celestial bodies' orbits and the characteristics of light and vision as special cases of a single conception of the conical function (Director, 2006). Hence he included in Paralipomena to Witelo, his major study in optics (1604), the anatomical plate by Felix Plattner showing the conical sections of the human eye, emphasizing thus the causal and formal connections between perception and vision (Kepler, 2000).

In Kepler's beautiful vision of the outer space, the planetary orbits did not simply occur in a dark void governed by mysterious gravitation forces. They are the consequence of the immaterial species which the solar body emanates rotating as if on a lathe, analogous to the immaterial species of its light. Rotating itself, this species carries the bodies of the planets with its strong grasp. This Latin word related to the verb specio has an extraordinary wide range of meanings. It is also the Latin equivalent of the Greek $\varepsilon 1 \delta \circ \sigma$, Plato's word for his forms or ideas. William $H$. Donahue, translator of Astronomia Nova chooses to leave this word untranslated since 


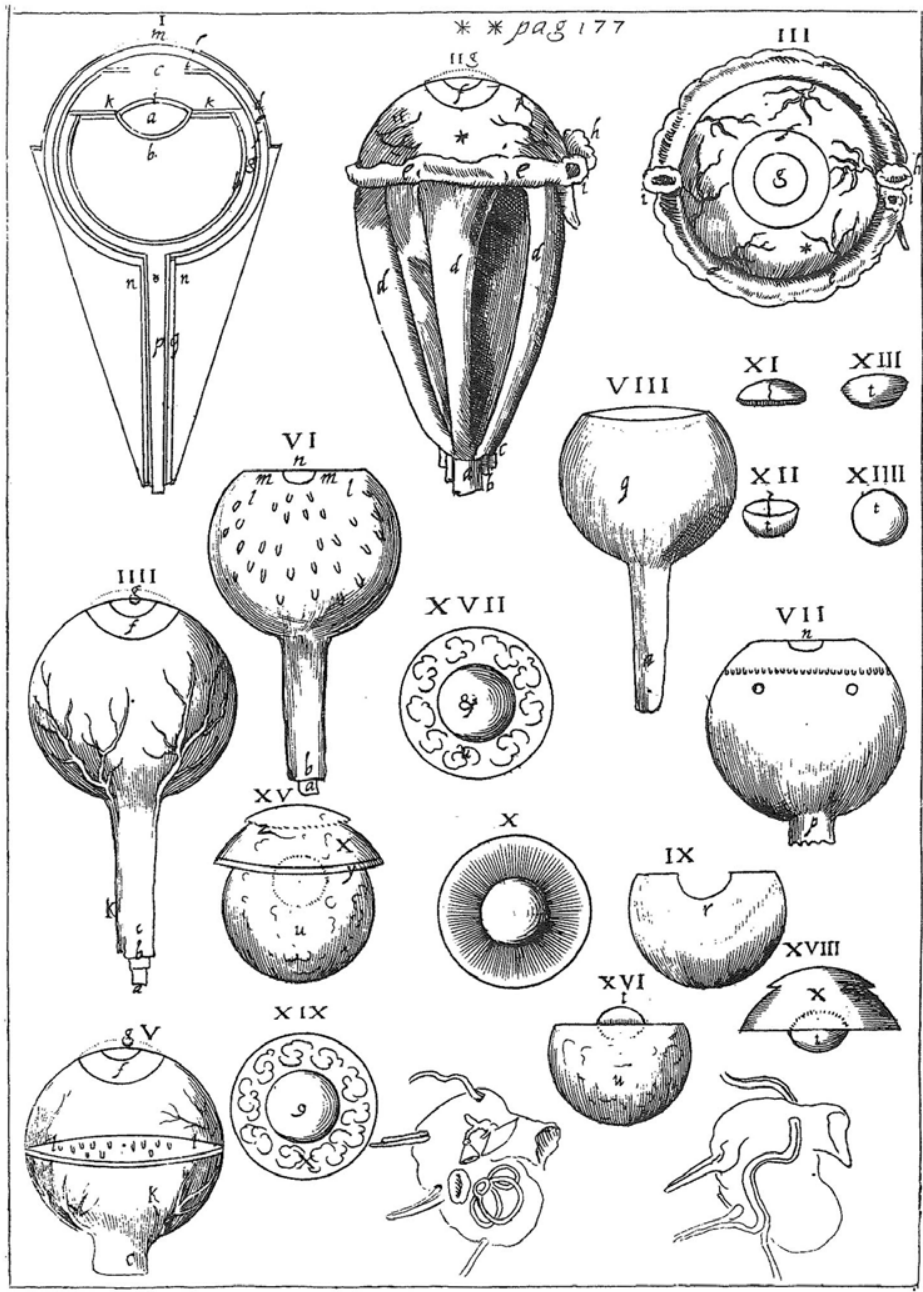

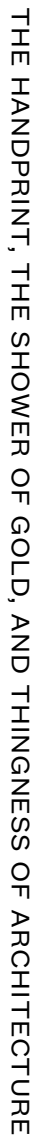

Fig.5: Felix Plattner's anatomical plate 49 from Johannes Kepler's Paralipomena to Witelo, 1604

there is no English word that can embrace so many meanings (Donahue, 2004). Kepler illustrated the movement of planets in the outer space with the circular river paradigm and sailor revolving his oar through the aethereal air, reminiscent of the ancient Egyptian vision of the celestial dome as the goddess Nut dressed in stars and water. Brought down to earth into the Danae's chamber, architectural space first appeared as something similar to aether, something more than the volume of air enclosed within a chamber and lit from above. It is also the species - form, image, appearance, kind, property, quality, type, surface, semblance, emanation, spectacle, atmosphere of the actual building - the quintessence and the THINGNESS OF ARCHITECTURE. 
Actually, and metaphorically, from the idea to the completion of a building, every work of architecture is within many a hand's grasp. Larger a work of architecture in terms of size, programme, site requirements, public interest etc., ever more hands get involved. The immediate matter of an architectural project is the ink or even less material digital media. As a physical fact, a project relates the imperishable forms to the actual presence. This relation involves nonverbal thinking (Mitrović, 2011) in terms of space, volume and shape which we project into material and structure whilst drawing scale plans, sections and details, detailing formwork plans, building digital three-dimensional models, applying building standards, calculating and writing ever more detailed descriptions. It would be possible, yet not plausible, to produce an architectural project entirely made of words and numbers instead of plans and sections. But, no matter how detailed, a project can never fully describe the building which is its final cause. Manifold agents enter the mind-to-hand connection already within conception of any project, and particularly within its construction as the contemporary cyclops take it in their hands. Questions appear along this non-linear way: Which color on a steel cylinder skin would best uncover the hand trace of those unknown agents? Would it be possible in thingness of this tense surface, to preserve a trace of heat involved in its production, the unintentional little imperfections which make it appear the skin of a giant reptile? Or, exactly which shape would show the right measure of shadow on a surface of a solid concrete wall? How to keep at least some properties of the liquid compound before it cools in casting? Can a curtain really be the thingness of a wall? How to substantiate the intended thingness of the projectin-progress into material presence: form, image, appearance, kind, quality, type, surface, semblance, emanation, spectacle, atmosphere? Whilst answering such questions aimed beyond simple materials and techniques, thin layer of glossy paint, specially designed formwork, opacity of concrete, translucency of Proconnesian marble blocks cut this way or another, we discover the thingness and the quintessence of architecture, first, through a project, second, throughout construction, and even afterwards - until the building turns to dust.

Architecture is eminently artificial human enterprise: die Baukunst, the art of building. In Die vier Elemente der Baukunst, Gottfried Semper defined the hearth as the first, moral element of architecture with three other elements grouped around it as "the protecting negations or defenders of the hearth's flame against the three hostile elements of nature," the roof against 


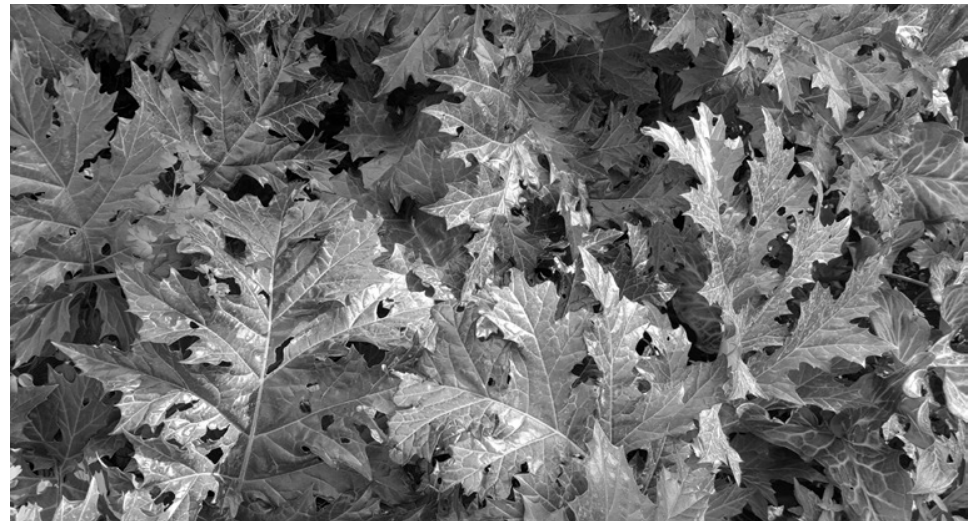

Fig. 6: Acanthus, Mali Lošinj, photo: author, 2016

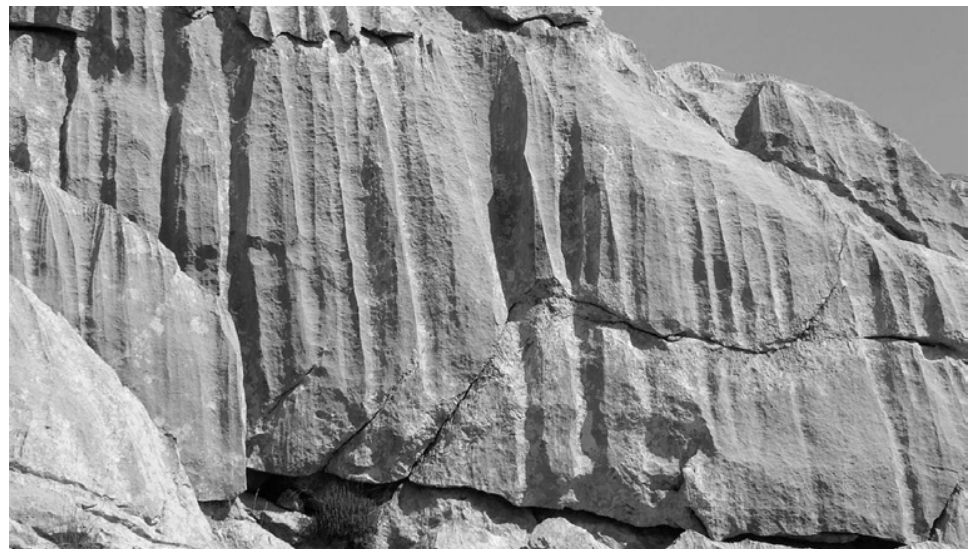

Fig. 7: Flutes in karst, limestone, Mt Velebit, photo (c) 2016, Tihomir Marjanac

water, the enclosure against air, and the mound against earth, with wild fire now domesticated in the center (Semper, 2011). Architecture is not mimesis of nature, and yet it is subject to natural laws and principles residing somewhere between the mineral world and vegetation: the principles of growth and distribution of loads against its own weight, the principles of resistance to forces of nature, the principles of formation of the earth's crust, mineralization of organic material and erosion. Architecture is eminently archaic, as the dominant epistemologies, pragmatic conditions and techniques may change, but fundamental notions, ideas and principles remain where they have been ever since the construction of the first shelter. Cyclops on the antediluvian construction-field are still there, in spite the ever-increasing mass of standards and rules, recipes and techniques, supposed improvement of natural and artificial materials. Architecture is also eminently thingly. "Architecture, like its great teacher, nature, should 
choose and apply its material according to the laws conditioned by nature, yet should it not also make the form and character of its creations dependent on the ideas embodied in them, and not on the material?", so Semper. Elaborating on the Vitruvian discovery of architecture around the camp fire, he went back to the origins while rejecting antiquarianism, the materialist way of thinking, and the mimesis of nature. To the four elements of architecture he associated primitive techniques, ur-crafts, which evolved around them - ceramics and metal works around the hearth, water and masonry works around the mound, carpentry around the roof, and the art of weaving around the enclosure. Thus, he subordinated not only bare materials and techniques but bare purposes too, to the things which constitute a work of architecture: the hearth, the roof, the enclosure, the mound, and consequently the chimney, the corniche, the window, the stairs, the railings, all the way to the smallest fittings and details.

Not coincidentally, that same year Semper first published his Four Elements of Architecture, 1851, The Great Exhibition of Industrial Works of All Nations opened, housed in the temporary structure virtually without any mound, roof or enclosure. In Winter Notes to Summer Impressions, horrified Fyodor Dostoevsky described his visit to the exhibition in summer 1862. The enormous stream of people, the perpetual event through the first building in modern history built to contain virtually anything, Heaven brought down to earth devoid of any metaphysical content... presented to Dostoevsky a perfect architectural paradigm of the world whose "brotherly fellowship and spiritual unity" were irretrievably broken, as Father Zosima would have phrased it. Since the exhibition building did not have any special name, Peter Sloterdijk assumed that it was Dostoevsky who named it the Crystal Palace, "as it were, immaterialized and artificially temperature-controlled building," the herald of our time, a perfectly neutral background instead of architecture, and instead of the old world of things the celebration of the new world of events.

Firmly anchored in the world of things, a thing itself made of things, every work of architecture is in opposition to this world of events. For better or for worse, in actual practice this opposition settles in the act of construction, as a project becomes a building: the mound, the hearth, the enclosure, the roof; the actual material, structure and space. In academia, this final cause of a project is usually out of reach. Hence is the most difficult part of our project courses the moment of substantiation of the intended thingness of the project-in-making into the material presence: form, image, kind, emanation, spectacle, atmosphere. Functional schemes and area calculations are of 

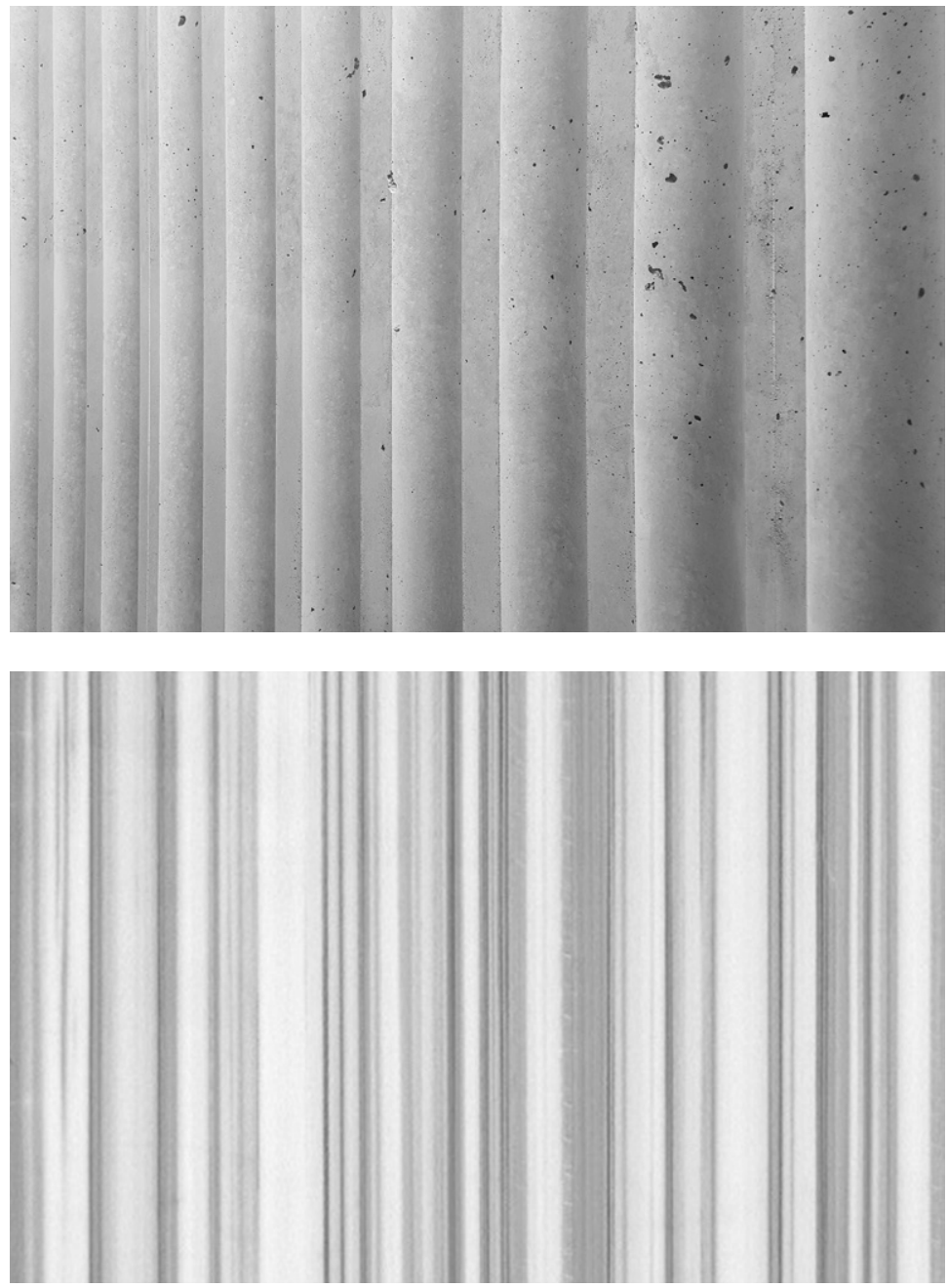

Figs. 8, 9: IVANIŠIN. KABASHI. ARHITEKTI, Curtain Wall: Fluted Concrete, Proconnesian Marble, 2019

little help here. Floor plans, sections, elevations, digital models, along with the analysis of relevant paradigms and examples suffice in the distribution of uses and the definition of basic spatial relations within the projected building and around the project site. Scale models and mockups, along with three-dimensional images and videos do bring students closer to the actual experience. Yet, only the authorities of well-substantiated contents of project courses and well-chosen project sites may virtually bring students closest to the unscalable final cause. Teacher's actual experience in construction and ability to transfer this experience along with all other theoretic, "artistic" and "scientific" aspects of architecture is crucial in broaching this end. 
The state of the education of future architects indeed is in the bidirectional cause-and-effect relation with the general state of architecture as a profession, discipline, venture, practice and as the actual art of building in the actual present. This actual present has at least three aspects: an ever-changing array of pragmatic conditions is subject to the dominant epistemologies (die Zeitgeist; "the will of the epoch...), together they are subject to the set of fundamental notions, ideas and principles (...translated into space"). Clearly, the pragmatic conditions for the most part concern the practice, and there is no reason to translate them verbatim into the schools of architecture. Any overemphasis into this direction would only intellectually impoverish the future architects. The education of future architects in general and particularly the project courses should concentrate around the second and the third aspects. In any ambitious school of architecture, they do. It is precisely the confusion of the hierarchy of those two aspects which makes the moment of substantiation of the projects-in-progress difficult. As a result of this confusion, the fundamental notions which inform the project are often marginalized and project courses tend to concentrate around irrational "artistic" and pseudo-rational "scientific" issues with technical or humanistic overtones. An overemphasis is put on the verbalization of the "process" and on the "research" but without much interest in the final cause and any clear idea what can be classified as the project-related research which would eventually contribute to the final cause. In the most extreme cases, students are taught how to speak, behave, and even think in certain ways instead of how to solve architectural problems. With nostalgia for good old times and uncritical enthusiasm for new trends, especially those coming outside the realm of architecture, i.e. with the elevation of the current epistemologies to the position of the fundaments, the species gets lost in an ocean of words and concepts - the dead end. "Instead of beauty - branding," instead of Ovid's Metamorphoses - Google Translator and Google Search, instead of site visits - Google Earth.

How to guide the studio projects beyond the banality of mechanical problems (is the project sustainable?), historical reference (is the project new and different?), and vague concepts (what does the project stand for in social, political and whatever other terms?)? In other words, how to communicate the thingness of architecture to students of architecture immersed into this ocean of words and concepts?

The ideal project brief which would surmount the ocean of words and concepts and explain the natural principles inherent 


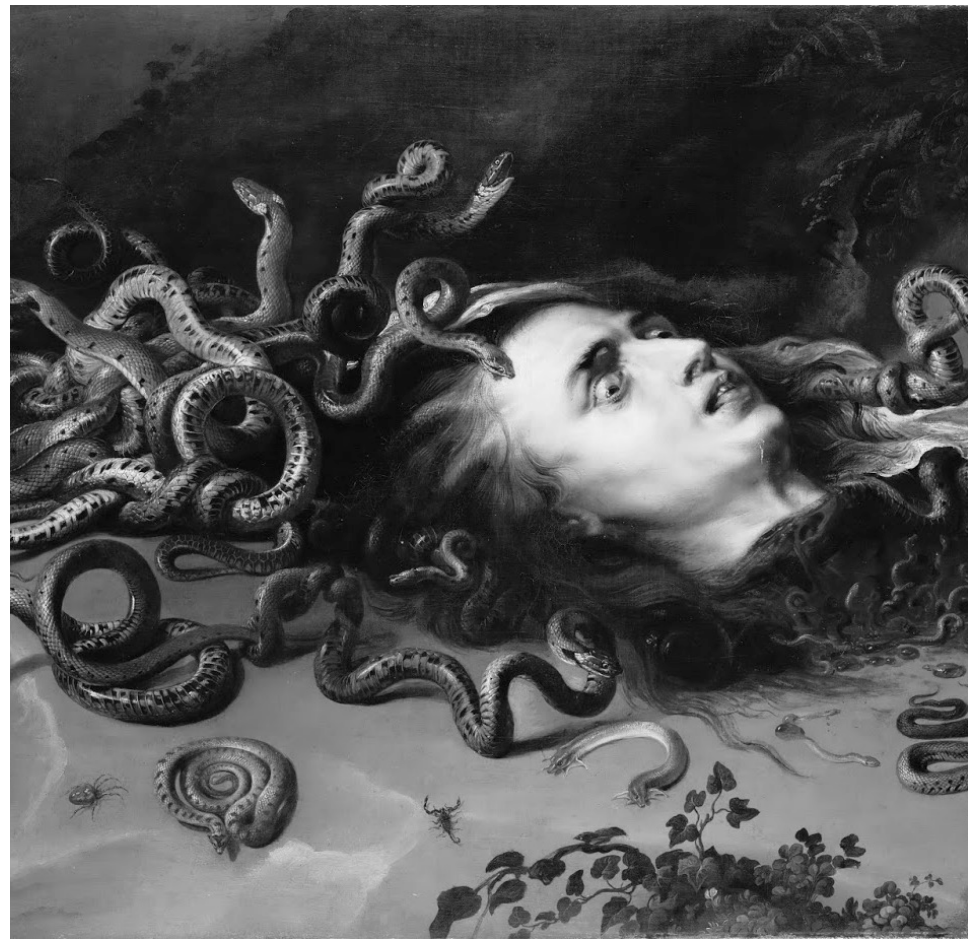

Fig. 10: Peter Paul Rubens, Head of Medusa, 1617

to works of architecture could be described as: (1) closer to place than to program, with the scope of place extended beyond the immediately visible, (2) archaic but not primitive fostering thus the interest into questions of architectural practice beyond the bare techniques, (3) that which puts the fundamental architectural notions such as form, volume, structure, material, space in the center of interest pertaining thus to the world of things instead of the world of events, and (4) relating the mind to the hand - the sublime myth to the everyday practice. The pre-archaic world was surrounded by the circular river Ocean, the brim towards the darkness inhabited by horrifying creatures. In the climax of his myth, Perseus had to fly westwards beyond the stream of Ocean in the frontier land towards Night and decapitate the chtonic monster who used to be a beautiful woman - the triumph of faith, hand and mind over schizophrenia, vanity and darkness. His bravery in the name of wisdom was justly rewarded with the permanent place up there in the starry firmament. In the happy conclusion of her myth, his sister Persephone divided the seasons between the mineral and the vegetative worlds governed by the natural principles of growth and weathering, composition and decomposition, which govern the world of architecture as well: 
"But Jove (with equal justice to his brother And to his stricken sister) cut the cycle Of the revolving year; and for their claims Six months to each, with Proserpina goddess For half the year on earth, the other half Queen with her husband; then at once her face And spirit changed, for even dark Death noticed A weary sadness spreading through her veins Now changed to joy; who, like the sun when held Behind grey mist and rain, now showers down His light through clouds and shows his golden face." 
Burckhardt, T. (2009). Art of Is/am. World Wisdom (https://www. slideshare.net/TaimurSuri/art-of-islam-titus-buckhardt)

Davey, Norman (1965). Storia del materiale da costruzione. Translated by Antonietta Mazza. Milano: Il Saggiatore

Director, B. (2006). On the 375th Anniversary of Kepler's Passing. Fidelio, XI(1-2). (https://r.schillerinstitute.org/ fid_02-06/2006/061-2_375_Kepler.html)

Donahue, W.H., ed. (2004). Selections from Kepler's Astronomia Nova. Green Lion Press

Dostoevsky, F. (2016). Winter Notes on Summer Impressions. Alma Books

Evelyn-White, H.G. (2005). Hesiod, Homeric Hymns and Homerica. Adelaide: University of Adelaide (https://ebooks.adelaide.edu. $\mathrm{au} / \mathrm{h} / \mathrm{hesiod} /$ white/complete.html)

Fathy, H. (1989). Architecture for the Poor. The American University in Cairo Press

FitzLyon, K. (2016). Preface to Dostoevsky. Winter NoteS

Goethe, J.W. (1840). Theory of Colours, translated by Charles Lock Eastlake. John Murray

Hesiod. (1914). The Theogony, II $270-280$, in: Evelyn-White. Hesiod, Homeric Hymns and Homerica

Isaiah 3:24, New International Version

Kepler, J. (2000). Optics; Paralipomena to Witello \& Optical Part of Astronomy, translated by William H. Donahue. Green Lion Press

Mies van der Rohe, L. (1924). Architecture and the Times, in: Johnson, P. (1978). Mies van der Rohe, The Museum of Modern Art

Mitrović, B. (2011). Philosophy for Architects. Princeton Architectural Press

Ovid (1958). The Metamorphoses, Book IV, translated by Horace Gregory. The Viking Press

Pausanias. (1918). Description of Greece, translated by W.H.S. Jones. (https://www.theoi.com/Text/Pausanias2B.html. 2.16.5)

Semper, G. (2011). The Four Elements of Architecture. Cambridge University Press

Sennett, R. (2008). The Craftsman. Allen Lane

Sloterdijk, P. (2005). In the World Interior of Capital: Towards a Philosophical Theory of Globalization, The Crystal Palace. Atlas of Places, June 2018. (https://www.atlasofplaces.com/ essays/the-crystal-palace/)

Torres, E. (2009). Light is for Free, in: Mateo, J.LI \& Sauter, F. Iconoclastia. Actar, LX 
